\section{Effectiveness of Two Apex Locators to Determine Simulated Horizontal Root Fractures}

\section{Farklı Seviyelerde Yapay Olarak Oluşturulmuş Horizontal Kö̀k Kırıklarının Tespitinde İki Apeks Bulucunun Doğruluğunun Karşılaştırılması}

\section{Assist. Prof Dilara Arslan}

İstanbul Aydın University, Faculty of Dentistry, Department of Endodontics, İstanbul

\section{Assist. Prof Demet Altunbas}

Cumhuriyet University, Faculty of Dentistry, Department of Endodontics, Sivas

Assoc. Prof Alper Kuştarcı

Akdeniz University, Faculty of Dentistry, Department of Endodontics, Antalya

Received: 25 August 2017

Accepted: 22 December 2017

doi: 10.5505/yeditepe.2018.22755

\section{Corresponding author:}

Assist. Prof. Dilara Arslan

İstanbul Aydın Üniversitesi, Diş Hekimliği Fakültesi

Endodonti Anabilim Dalı, İnönü caddesi No:38 34295 İstanbul

Tel: 00902124113000

E-mail: dilaraarslan@aydin.edu.tr.

\section{SUMMARY}

Aim: The aim of this study was to evaluate in vitro the effectiveness of the two different electronic apex locators (Dentaport ZX and Rootor-EALs) in locating simulated horizontal root fractures.

Materials and Methods: Forty extracted human single-rooted teeth with mature apices were randomly divided into two groups of 20 teeth each. An incomplete horizontal fracture was simulated by preparing a with a $0.25 \mathrm{~mm}$ thick disk in the middle and apical portion of the root and the teeth were mounted in an alginate mold. The electronic measurements (ELs) of the simulated root fractures were established with a size $10 \mathrm{~K}$-file by each EAL in both fracture levels. The actual canal lenghts (ALS) were measured under a stereomicroscope. The ALs were subtracted from the ELs of the fractures. The data were analyzed using the Mann-Whitney $U$ and the Wilcoxon signed-rank tests at a significance level of $\mathrm{P}<.05$.

Results: The mean differences between the ELs and ALs were $-0.12 \pm 0.27 ; 0.09 \pm 0.38 ;-0.10 \pm 0.25 ; 0.18 \pm 0.53 \mathrm{~mm}$ in the Dentaport ZX and Rootor groups and middle and apical horizontal fracture levels, respectively. The Dentaport ZX performed measurements within $\pm 0.5 \mathrm{~mm}$ in 18 and in 19 samples while the Rootor performed in 12 and in 11 samples, middle and apical horizontal fracture levels respectively. Statistically, significant differences were found among the EALs at both horizontal fracture levels $(P<.05)$. However; no statistically significant differences were found between the fracture levels in each of the EALs $(P>.05)$.

Conclusions: The Dentaport ZX measurements were shorter than ALs whereas the Rootor measurements were longer than Als. Furthermore, the number of measurements obtained within $\pm 0.5 \mathrm{~mm}$ in Dentaport ZX is more than that of Rootor. Under the conditions of this study, the Dentaport ZX group showed an acceptable determination of the horizontal root fracture.

Key words: Apex locator, Dentaport ZX, horizontal root fractures, Rootor

\section{ÖZET}

Amaç: Bu çalışmanın amacı yapay olarak oluşturulan horizontal kök kırıklarının teşhisinde iki farklı elektronik apeks bulucu cihazın (Dentaport ZX and Rootor) etkinliğinin karşılaştırımasıdır.

Gereç ve Yöntem: 40 adet tek köklü çekilmiş daimi diş her bir grupta 20 adet olmak üzere 2 guruba ayrıldı. $0.25 \mathrm{~mm}$ kalınlığında elmas separe kullanılarak köklerin orta ve apikal üçlü hizasında horizontal kırık hatları oluşturuldu. Aljinat model içine yerleştirilen kökler üzerinde her iki apeks bulucu ile horizontal kırık hatlarının tespiti $10 \mathrm{~K}$ eğesi kullanılarak yapıldı. Gerçek ölçümler aynı eğe kullanılarak stereomikroskop (SMZ 800, Nikon, Tokyo, Japan) kullanılarak tespit edildi. Gerçek ve elektronik ölçümler arasındaki fark hesaplandı. İstatistiksel incelemelerde Mann-Whitney U ve Wilcoxon Eşleştirilmiş Ik 
Örnek Testi testleri kullanıldı.

Bulgular: Dentaport ZX ve Rootor apeks bulucuların orta ve apikal horizontal kırık seviyelerinde elektronik ve gerçek ölçümlerin farklarının ortalamaları sırası ile $-0.12 \pm$ $0.27 ; 0.09 \pm 0.38 ;-0.10 \pm 0.25 ; 0.18 \pm 0.53$ mm'dir. Dentaport ZX orta horizontal kırık seviyesinde 18 örnekte ve apikal horizontal kırık seviyesinde 19 örnekte, Rootor ise orta horizontal kırık seviyesinde 12 örnekte ve apikal horizontal kırık seviyesinde 11 örnekte gerçek ölçümlere kıyasla $\pm 0,5 \mathrm{~mm}$ içerisinde tespitler yapmıştır. Her iki kırık seviyesinde Dentaport ZX ile Rootor'a ait ölçüm değerleri arasındaki farklılık istatistiksel olarak önemli bulunmuştur $(p<05)$. Ancak Dentaport ZX ile Rootor gruplarının kendi içerisinde orta ve apikal kırık seviyeleri ölçüm değerleri arasında istatistiksel farklıık tespit edilmemiştir ( $p>0$.05).

Sonuç: Dentaport ZX ile yapılan ölçümler gerçek ölçümlerden daha kısa tespit edilirken, Rootor ölçümleri daha uzun tespit edilmiştir. Ayrıca $\pm 0.5 \mathrm{~mm}$ içerisinde elde edilen ölçüm sayısı Dentaport ZX'de Rootora göre daha fazladır. Bu koşullar altında; Dentaport ZX ile yapılan ölçümlerin daha kabul edilebilir olduğunu söyleyebiliriz.

Anahtar kelimeler: Apex bulucu, Dentaport ZX, horizontal kök kırığı, Rootor

\section{INTRODUCTION}

Root fractures, which may be oblique, vertical and horizontal, are among the most difficult cases in clinical endodontic practice, especially when they are not completed.' Because of the restrictions of the clinical and radiological examination accurate diagnosis of these fractures is still a challenge. ${ }^{2}$ Often, the coronal segment of the pulp of teeth with fractured roots will become non vital over time; thus it is recommended to implement root canal treatment up to fracture line and leave the apical root canal segment untreated. ${ }^{2,3}$ When we decide to perform root canal treatment for a tooth with a root fracture, the first factor that will alert us may be is the electronic apex locator (EAL) devices. Theoretically, EALs mark apex from the beginning of the defect because of the periodontal connections. ${ }^{4,5}$

All EALs function by using the human body to complete an electrical circuit. ${ }^{6}$ Suzuki ${ }^{7}$ recorded steady measurements in electrical resistance between an instrument in a root canal and an electrode on the oral mucous membrane and assumed that this would measure the canal length. Sunada ${ }^{8}$ followed these principles to construct the first simple EAL device to measure the canal length. For more than 60 years, new generation devices have been developed and have gained increasing acceptance because of high precision in determining the working length. 6 Thanks to these principles, any connection between the root canal and the periodontal membrane, such as root fracture, cracking and internal or external root resorption, will be recognised by the EAL. ${ }^{9,10}$

The Dentaport ZX (Morita, Tokyo, Japan) is an EAL that measures the impedance at two frequencies (0.4 and 8 $\mathrm{kHz})$, requires no calibration, and accurately measures the moisture conditions inside canal..$^{11}$ It is composed of two modules: the Root ZX and the Tri Auto ZX.12,13 The Rootor (Meta Biomed Cheongwon-gun, Korea) is a multiple-frequency EAL that uses two frequencies (0.5 and 5 $\mathrm{kHz})^{14,15}$

No comparative analysis has been performed regarding the use of these EALs for locating horizontal fractures. Thus, the aim of this investigation was to evaluate the ability of the Dentaport ZX and the Rootor EALs to determine simulated horizontal root fractures in vitro using an alginate model.

\section{MATERIALS AND METHODS \\ Selection and Preparation of Teeth}

Forty freshly extracted human maxillary anterior teeth with mature apices and straight root canals without any crack or perforations were selected. The reasons for the extraction were not related to this study. The external surfaces of the teeth were cleaned with an ultrasonic scaler (EMS Pieazon Master 400, CH-1260 Nyon, Switzerland). The teeth were viewed radiographically in a buccolingual and mesiodistal plane, and teeth with calcification, more than one canal and apical foramen or endodontic treatment were excluded from the study. The 40 teeth selected with these criteria were immersed in $4{ }^{\circ} \mathrm{C}$ distilled water until use.

The teeth were decoronated at the cementoenamel junction using a high-speed diamond disk with a cooling system to achieve a flat surface and standardize the root length of $16 \mathrm{~mm}$. The contents of the canals were removed with a proper barbed broach. The patency of the apical foramen was controlled with a size $10 \mathrm{~K}$-file (Dentsply Maillefer, Ballaigues, Switzerland). Subsequently; the canals were irrigated with $2.5 \mathrm{~mL} 2.5 \%$ sodium hypochlorite followed by $2.5 \mathrm{~mL}$ distilled water.

The forty roots were randomly divided into two experimental groups $(n=20)$ for simulation of horizontal fractures in two different regions. An incomplete horizontal root fracture was simulated by preparing a horizontal incision with a diamond disc in the middle (Group 1: $8 \mathrm{~mm}$ from the anatomic apex) or apical (Group 2: $4 \mathrm{~mm}$ from the anatomic apex) portion of the canal. Roots were cut until the root canal was exposed. The thickness was approximately $0.25 \mathrm{~mm}$.

\section{Electrical measurements}

The specimens were placed into freshly mixed alginate, which was poured into a plastic mold, leaving a coronal $2 \mathrm{~mm}$ of the root. The Dentaport ZX and the Rootor EALs 
were used in accordance with the manufacturer's instructions for locating simulated horizontal fractures. The root canals were irrigated with a $0.9 \%$ saline solution with a 27-gauge needle, and the coronal plane surfaces were gently dried with a cotton pellet. The labial clip of the EALs was also inserted into the alginate, and the instrument clip was attached using a size $15 \mathrm{~K}$-file. For the Dentaport ZX device, the measurements of the canal length was recorded when the file was withdrawn until the last green bar had been reached on the display after going through the 'APEX' (red bar lit). For the Rootor, the file was advanced until the last red led ' 00 '.

Then, both EALs, a rubber stop on the file was carefully adjusted to the reference level. The distance between the rubber stop and the file tip was measured with a caliper to the nearest $0.05 \mathrm{~mm}$ and the readings were recorded (ELs).

All measurements were made in an interval of $2 \mathrm{~h}$, with the alginate gel kept sufficiently humid for this time.

\section{Actual length measurements}

The roots were removed from the alginate; the fracture was completed with the same disc, and the actual canal lenghts (ALs) were measured with a size $15 \mathrm{~K}$-file under a stereomicroscope (SMZ 800, Nikon, Tokyo, Japan).

The electronic and actual lengths were all measured by a single endodontist. All measurements were performed 3 times and the averages of the measurements were taken.

\section{Statistical Analysis}

For each EAL, the ALs were subtracted from the electronic lengths (ELs) of the fractures and the differences were noted. Negative and positive values indicated measurements that were shorter and longer than the $A L$, respectively, whereas 0.0 indicated coinciding measurements. IBM SPSS 20 Software (IBM SPSS Inc., Armonk, NY, USA) was used for all statistical analyses. A significance level of 0.05 was used for all statistical tests. The results were statistically analyzed using the Mann-Whitney $U$ and the Wilcoxon signed-rank tests at a significance level of $p<.05$.

\section{RESULTS}

Table 1 shows the mean difference between the EL and the $\mathrm{AL}$ of the horizontal fracture at different levels of the root with the standard deviation (SD) for each EAL. The distribution of frequency (\%) of the distance between the EL and the AL according to the horizontal fracture level for each device is shown in Table 2. Statistically significant differences were found among the EALs at both horizontal fracture levels, $(p<0.05)$. However; no statistically significant difference was found between the fracture levels in each EAL group ( $p>0.05)$.
Table 1. The mean difference between the electronic length and the actual length of the horizonta fracture with the standard deviation for each electronic apex locator in different level of the root

\begin{tabular}{|c|c|c|c|}
\hline \multirow{2}{*}{ Group } & \multirow{2}{*}{$\mathbf{n}$} & Dentaport ZX & Rootor \\
\hline & & Mean \pm SD & Mean \pm SD \\
\hline Middle & 20 & $-0.12 \pm 0.27^{\mathrm{a}}$ & $0.09 \pm 0.38^{b}$ \\
\hline Apical & 20 & $-0.10 \pm 0.25^{\mathrm{a}}$ & $0.18 \pm 0.53^{\mathrm{b}}$ \\
\hline
\end{tabular}
difference $(P<.05)$.

Table 2. Distribution of frequency (\%) of the distance between the electronic length and the actua length according to the horizontal fracture level for each device

\begin{tabular}{|c|c|c|c|c|c|}
\hline \multirow{2}{*}{ Group } & \multirow{2}{*}{$\begin{array}{c}\text { Distance from the actual } \\
\text { lenght }(\mathrm{mm})\end{array}$} & \multicolumn{2}{|c|}{ Dentaport ZX } & \multicolumn{2}{|c|}{ Rootor } \\
\hline & & $\mathbf{n}$ & $\%$ & n & $\%$ \\
\hline \multirow{5}{*}{ Middle } & 1.0 to 0.51 & 0 & 0 & 2 & 10 \\
\hline & 0.01 to 0.5 & 5 & 25 & 11 & 55 \\
\hline & 0 & 4 & 20 & 0 & 0 \\
\hline & -0.01 to $-0.5^{*}$ & 9 & 45 & 1 & 5 \\
\hline & -1 to $-0.51^{*}$ & 2 & 10 & 6 & 30 \\
\hline \multirow{5}{*}{ Apical } & 1.0 to 0.51 & 0 & 0 & 7 & 35 \\
\hline & 0.01 to 0.5 & 6 & 30 & 6 & 30 \\
\hline & 0 & 1 & 5 & 1 & 5 \\
\hline & -0.01 to $-0.5^{*}$ & 12 & 60 & 4 & 20 \\
\hline & -1 to $-0.51^{*}$ & 1 & 5 & 2 & 10 \\
\hline
\end{tabular}

${ }^{*}$ Negative values indicate measurements short of the actual canal length

\section{DISCUSSION}

Root fractures constitute nearly $7 \%$ of endodontic trauma cases. Although three different radiograph angulations have been recommended for the detecting the fracture line, the location of the fracture plane is also still difficult to detect. ${ }^{2}$ Within the first hour after the dental trauma, we were not able to mark fractures by means of radiographs. In such cases, it is possible for the coronal root segment to lose vitality while the apical segment remains vital. In such cases it may be necessary to apply canal treatment to the coronal portion of the fracture line..$^{16}$ EALs are capable of recording the point at which the tissues of the periodontal ligament begin outside the canal by measuring electrical properties so that they mark the first point that has periodontal communication as the apex. 1,17

In many in vitro studies evaluating the accuracy of EALs, different electroconductive materials, such as agar, alginate, saline gelatin, flower sponge have been used to simulate the clinical situation. ${ }^{18,19}$ Baldi et al. ${ }^{17}$ carried out a study to compare these media, and the results showed that alginate provided the most coherent results with the actual working length. Therefore, in the current study, alginate was selected as a medium to simulate the normal periodontium.

Several in vitro researches have assessed the accuracy of various EALs such as Justy II, ProPex, NovApex, Elements Apex Locator, Root ZX, Foramatron D10, Apex NRG TCM Endo V, Tri Auto ZX, and Raypex-4 in locating the horizontal fractures. All of these studies showed that EALs detected the root fractures within a clinically acceptable range. $13,9,20,21$ To the best our knowledge, no published studies have evaluated the Rootor or Dentaport ZX for detecting horizontal fracture. In the present study, horizontal fractures were simulated at the 4 and $8 \mathrm{~mm}$ from the apex of the roots. According to the results of this study, which examined these devices for this purpose, the Dentaport ZX and Rootor, were acceptable. However, the Dentaport 
ZX was more successful in the detection of horizontal fractures than the Rootor at both levels. It was not possible to compare the Rootor with other existent studies because of the lack of research on this device's location of horizontal fractures. Altunbaş et $\mathrm{al}^{14}$ reported that the Dentaport ZX and Rootor detected the root canal perforations within a clinically acceptable range. These results are in agreement with the above-mentioned studies.

Many studies have used $\mathrm{a} \pm 0.5 \mathrm{~mm}$ error range to assess the accuracy of the EALs ${ }^{22,23}$, and others have relied on a range of $\pm 1.0 \mathrm{~mm} .{ }^{11,24}$ Measurements within these tolerances were considered accurate and clinically acceptable in the present study because the relation between the rubber stop and the reference point, the rubber stop and the caliper, or the file tip and the caliper was difficult to control visually. The present results indicate that both devices were acceptable because all difference values were within the range of $\pm 1.0 \mathrm{~mm}$. The Dentaport ZX detected the middle horizontal root fracture within $\pm 0.5 \mathrm{~mm}$ in 18 samples (90\%) and the apical horizontal fracture in 19 cases (95\%). The Rootor detected the middle and apical horizontal fracture within $\pm 0.5 \mathrm{~mm}$ in 12 cases $(60 \%)$ and in 11 cases (55\%), respectively (Table 2). There was no measurement showing error of $1 \mathrm{~mm}$ or more. In root fractures, the accuracy of the EAL is important to prevent under or over instrumentation. Because the Dentaport ZX measurements were shorter than actual measurements in general, we are of the opinion that the Dentaport ZX is more acceptable than the Rootor in the present study. A comparison of the SD is also helpful for assessing the reliability of the measurements. According to Lee et al 25, the reproducibility of the measurements in a consistent manner, as measured by the SD, is more important than knowing the mean distance from the measurements to the $\mathrm{AL}$. If the reading of the device is consistent, a low SD is obtained. In the present study, the findings obtained with the Dentaport ZX device were more consistent than those for the Rootor device, especially in the apical horizontal fractures.

\section{CONCLUSION}

The Dentaport ZX measured (on average) shorter than the real measurements, while the Rootor measured longer than the real measurements. Under the conditions of this study, the two tested EALs were accurate and acceptable clinical device for detecting the position of horizontal fractures when $\pm 1.0 \mathrm{~mm}$ of error is considered. However; the Dentaport ZX was more successful in the detection of horizontal fractures than the Rootor, at both levels. It should be emphasized that the results obtained from in vitro studies cannot be directly extrapolated to the clinical situation, and further clinical examinations of the use of EALs are needed.

\section{Acknowledgments}

The authors deny any conflicts of interest related to this study.

\section{REFERENCES}

1.Topuz O, Uzun O, Tinaz AC, Bodrumlu E, Gorgul G. Accuracy of two apex-locating handpieces in detecting simulated vertical and horizontal root fractures. J Endod 2008; 34: 310-313.

2.Lindhal B. Transverse intraalveolar root fractures: roentgen diagnosis and prognosis. Odont Revy 1958; 9: 10-24. 3.Goldberg F, Frajlich S, Kuttler S, Manzur E, Briseno-Marroquin $B$. The evaluation of four electronic apex locators in teeth with simulated horizontal oblique root fractures. J Endod 2008; 34: 1497-1499.

4.Pallares $A$, Faus $V$. An in vivo comparative study of two apex locators. J Endod 1994; 20: 576-579.

5.Fuss Z, Assooline LS, Kaufman AY. Determination of location of root perforations by electronic apex locators. Oral Surg Oral Med Oral Pathol Oral Radiol Endod 1996; 82: 324-329.

6.Gordon MP, Chandler NP. Electronic apex locators. Int Endod J 2004; 37: 425-437.

7.Suzuki K. Experimental study on iontophoresis. J Jpn Stomatol 1942; 16: 411-429.

8.Sunada I. New method for measuring the lenght of the root canal. J Dent Res 1962; 41: 375-387.

9.Ebrahim AK, Wadachi R, Suda H. Accuracy of three different electronic apex locators in detecting simulated horizontal and vertical root fractures. Aust Endod J 2006; 32: 64-69.

10.Nahmias Y, Aurelio JA, Gerstein H. Expanded use of the electronic canal length measuring devices. J Endod 1983; 9: 347-349.

11.Cimilli $H$, Aydemir S, Arican B, Mumcu G, Chandler N, Kartal N. Accuracy of the Dentaport ZX apex locator for working length determination when retreating molar root canals. Aust Endod J 2014; 40: 2-5.

12. Kustarci A, Arslan D, Altunbas D. In vitro comparison of working length determination using three different electronic apex locators. Dent Res J 2014; 11: 568-573.

13.Pascon EA, Marrelli $M$, Congi $O$, Ciancio R, Miceli $F$, Versiani MA. An in vivo comparison of working length determination of two frequency-based electronic apex locators. Int Endod J 2009; 42: 1026-1031.

14. Altunbas D, Kustarci A, Toyoglu M. The Influence of Various Irrigants on the Accuracy of 2 Electronic Apex Locators in Locating Simulated Root Perforations. J Endod 2017; 43: 439-442

15. Altunbas D, Kustarci A, Arslan D, Er K, Kocak S. Comparison of various current electronic apex locators to determine the working length using the clearing technique. 
Niger J Clin Pract 2015; 18: 359-363.

16.Cvek M, Mejare I, Andreasen JO. Conservative endodontic treatment of teeth fractured in the middle or apical part of the root. Dent Traumatol 2004; 20: 261-269.

17.Baldi JV, Victorino FR, Bernardes RA, de Moraes IG, Bramante CM, Garcia RB, et al. Influence of embedding media on the assessment of electronic apex locators. J Endod 2007; 33: 476-479.

18.Czerw RJ, Fulkerson MS, Donnelly JC. An in vitro test of a simplified model to demonstrate the operation of electronic root canal measuring devices. J Endod 1994; 20: 605-606.

19.Ushiyama J. New principle and method for measuring the root canal length. J Endod 1983; 9: 97-104.

20.Azabal M, Garcia-Otero D, de la Macorra JC. Accuracy of the Justy II Apex locator in determining working length in simulated horizontal and vertical fractures. Int Endod $J$ 2004; 37: 174-177.

21.al Kadi $H$, Sykes LM, Vally Z. Accuracy of the Raypex-4 and Propex apex locators in detecting horizontal and vertical root fractures: an in vitro study. SADJ 2006; 61: 244247.

22. D'Assuncao FL, Sousa JC, Felinto KC, de Medeiros TC, Leite DT, de Lucena RB, et al. Accuracy and repeatability of 3 apex locators in locating root canal perforations: an ex vivo study. J Endod 2014; 40: 1241-1244.

23.Shin HS, Yang WK, Kim MR, Ko HJ, Cho KM, Park SH, et al. Accuracy of Root $Z X$ in teeth with simulated root perforation in the presence of gel or liquid type endodontic irrigant. Restor Dent Endod 2012; 37: 149-154.

24. Herrera M, Abalos C, Lucena C, Jimenez-Planas A, Llamas R. Critical diameter of apical foramen and of file size using the Root ZX apex locator: an in vitro study. J Endod 2011; 37: 1306-1309.

25.Lee SJ, Nam KC, Kim DW. Clinical accuracy of a new apex locator with an automatic compensation circuit. J Endod 2002; 28 706-709. 